\title{
EFFECTS OF PHYSICAL THERAPY ON ELECTRODIAGNOSTIC PARAMETERS AND QUALITY OF LIFE OF PATIENTS WITH DISTAL SYMMETRIC SENSORIMOTOR DIABETIC POLYNEUROPATHY
}

\author{
Vesna Grbovic1, Aleksandra Jurisic Skevin 1,2, Aleksandar Djukic 2,3, Mirjana Petrovic ${ }^{4}$, Natasa Zdravkovic Petrovic ${ }^{2}$ \\ 'Center for Physical Medicine and Rehabilitation, Clinical Center "Kragujevac", Kragujevac, Serbia \\ ${ }^{2}$ Faculty of Medical Sciences, University of Kragujevac, Kragujevac, Serbia \\ ${ }^{3}$ Center for Endocrinology, Diabetes and Metabolic Diseases, Clinical Center "Kragujevac", Kragujevac, Serbia \\ ${ }^{4}$ Clinic for Neurology, Clinical Center "Kragujevac”, Kragujevac, Serbia

\section{EFEKAT FIZIKALNE TERAPIJE NA ELEKTRODIJAGNOSTIČKE PARAMETRE I KVALITET ŽIVOTA BOLESNIKA SA DISTALNOM SIMETRIČNOM SENZOMOTORNOM DIJABETESNOM POLINEUROPATIJOM}

\author{
Vesna Grbović1, Aleksandra Jurišić-Škevin 1,2, Aleksandar Đukić2,3, Mirjana Petrović4, Nataša Zdravković Petrović \\ ${ }^{1}$ Centar za fizikalnu medicinu i rehabilitaciju, Klinički centar „,Kragujevac“, Kragujevac \\ ${ }^{2}$ Fakultet medicinskih nauka Univerziteta u Kragujevcu, Kragujevac \\ ${ }^{3}$ Centar za endokrinologiju, dijabetes $i$ bolesti metabolizma, Klinički centar ,,Kragujevac“, Kragujevac \\ ${ }^{4}$ Klinika za neurologiju, Klinički centar ,Kragujevac“, Kragujevac
}

\section{ABSTRACT}

Objective. To determine effects of physical therapy on electrodiagnostic parameters of peroneal and sural nerves (conduction velocity, latency, amplitude) and on the quality of life of patients with distal symmetric sensorimotor diabetic polyneuropathy (DSPN).

Methods. The clinical study included 30 subjects who suffer from type 2 diabetes mellitus and who had been diagnosed with DSPN based on clinical symptoms, signs and parameters of the nerve conduction study. Each of those 30 patients was treated with the identical combination of physical agents: pulsed electromagnetic field and kinesitherapy. Physical therapy was conducted within three ten-days cycles (five days a week), with a two-month break between the cycles. At the time of admission and after the end of the third series of therapy, an analysis of the following parameters was conducted: European EuroQol (EQ-5D) test and the Short-Form McGill Pain Questionnaire (SF-MPQ).

Results. After completion of all three series of physical therapy statistics indicated a significant increase of conduction velocity of the left peroneal nerve $(p=0.027)$ and the sural nerve - both sides (right $p=0.0063$, left $p=0.005$ ). There was a significant reduction of latency for peroneal in both sides (right $p=0.003$; left $p=0006$ ). Analysis of these results indicated statistically notably high reduction of pain sensations/nuisance $(p<0.001)$ and highly significant reduction of worry/depression after physical procedures $(p<0.001)$. Furthermore, there was a statistically significant increase in $E Q-V A S$ values after physical procedures $(p<0.001)$.

Conclusion. The results attained in this research encourage further use of physical therapy agents in treatment of sensorimotor diabetic polyneuropathy.

Key words: diabetic neuropathies; pain measurement; quality of life; electromagnetic fields; exercise therapy.

\section{SAŽETAK}

Cilj. Utvrditi efekat fizikalne terapije na elektrodijagnostičke parametre $n$. peroneusa $i n$. suralisa (brzinu provođenja, latenciju, amplitudu) i na kvalitet života kod bolesnika sa distalnom simetričnom senzomotornom dijabetesnom polineuropatijom.

Metode. Kliničkom studijom obuhvaćeno je 30 ispitanika koji boluju od diabetes mellitusa tip 2 i kod kojih je na osnovu kliničkih simptoma $i$ znakova $i$ parametara elektromioneurografskog nalaza postavljena dijagnoza $D S P N$. Svaki od 30 bolesnika lečen je identičnom kombinacijom fizikalnih agenasa: pulsirajućim elektromagnetnim poljem $i$ kineziterapijom. Fizikalna terapija je sprovedena $u$ tri desetodnevne serije (pet dana $u$ nedelji), sa pauzom od dva meseca između serija. Prilikom prijema bolesnika $i$ po završetku treće serije terapija analizirani su sledeći parametri: Evropski test za ispitivanje kvaliteta života (EuroQol; EQ-5D) $i$ kratka forma Mekgilovog upitnika o bolu.

Rezultati. Nakon sprovedene sve tri serije fizikalne terapije došlo je do statistički značajnog povećanja brzine provođenja levog $n$. peroneusa $(p=0,027)$ i oba $n$. suralisa (desnog $p=0,0063 ;$ levog $p=0,005)$. Statistički je značajno smanjena latenca za oba $n$. peroneusa (desnog $p=0,003$; levog $p=0,006)$. Analiza rezultata je ukazala na statistički visoko značajno smanjenje osećaja bola/nelagodnosti $(p<$ 0,001) $i$ visoko značajno smanjenje osećaja brige/potištenosti nakon sprovedenih fizikalnih procedura ( $p$ $<0,001)$. Uočeno je $i$ statistički značajno povećanje vrednosti $E Q-V A S$ nakon sprovedenih fizikalnih procedura ( $p$ $<0,001)$.

Zaključak. Dobijeni rezultati ohrabruju dalju primenu agenasa fizikalne terapije u lečenju senzorimotorne dijabetesne polineuropatije.

Ključne reči: dijabetesne neuropatije; procena bola; kvalitet života; elektromagnetna polja; terapija vežbanjem. 


\section{INTRODUCTION}

Diabetic distal symmetric sensorimotor polyneuropathy (DSPN) is a diffuse, symmetric and chronic damage of the peripheral nerves. It is the main complication caused by diabetes that affects the quality of life, morbidity and expenses from the perspective of public health exploitation $(1,2)$. The painful diabetic polyneuropathy occurs in $16 \%$ of all the patients suffering from diabetes. It is often not reported (12.5\%) and not treated (39\%) (3). Clinically, it is manifested as a persistent or occasional pain localized mainly in the feet and provoked by the slightest touch; aggravated during the night and reduced during a walk (4). Degraded quality of life is manifested as a loss of self-control and independency in performance of many regular daily activities, as well as reduction of working abilities.

The most objective non-invasive method of evaluation of distal sensorimotor polyneuropathy is the nerve conduction study (NCS), especially important in detecting the subclinical signs of the illness. The earliest electrophysiological signs are reduced amplitude of sensory neurography, especially of the sural nerve, and prolonged distal sensory latency. In the clinically evident neuropathy, reduction of sensory and motor conduction velocity is obvious, especially in the legs where the peripheral nerves are the longest. The degree of conduction velocity reduction is proportional to the degree of development of the basic illness. Demyelination (partial or diffuse) reduces the nerve conduction velocity. The level of action potential is proportional to the number of conducting nerves. Lowered potential amplitude indicates a damage of axon (5). Considering that 246 million of people in the world are suffering from diabetes at the moment, and that the number is expected to increase up to 380 million until 2025 , it is necessary to introduce new methods in the treatment of health complications caused by diabetes (6).

Physical therapy is becoming more and more frequently used in treatment of diabetic DSPN patients, primarily as an analgesic therapy, however there have not yet been any major research studies about the effects of physical therapy on electrodiagnostic parameters. The aim of this study is to determine the effects of physical therapy on the electrodiagnostic parameters, motor and sensory nerve conduction velocity in the peroneal nerve and the sural nerve, amplitude and latency and on the quality of life of patients with DSPN.

\section{PATIENTS AND METHODS}

The prospective clinical study, conducted in the Center for Physical Medicine and Rehabilitation, of the Clinical Center Kragujevac between September 2007 and November 2009, included 30 subjects suffering from the type 2 diabetes mellitus (DM2), who have been diagnosed with DSPN based on the clinical symptoms, signs and electrodiagnostic findings.

The patients were referred to the Center for Physical Medicine and Rehabilitation by the neurologists from the Clinic for Neurology, Clinical Center Kragujevac, where nerve conduction study was done and where DSPN within DM2 diagnosis was determined. The study included diabetics who were subjects to successful drug therapy, resulting in good glycemia regulation (with the level of $\mathrm{HbAlc}$ under $8 \%$ ), and who had had symptoms and signs related to DSPN for more than two months.

Exclusion criteria were bad glycemia regulation (HbAlc above 8\%), existence of another disease in addition to diabetes, which could be in any way related to the origins of the neuropathy (immunodeficiency disorders, serious liver or kidney disease, heart failure, brain ischemia, psychiatric diseases, including alcoholism, application of chemotherapy) and existence of any condition because of which the above mentioned physical agents could not be applied (pregnancy, fever, malignancy, acute infectious diseases, presence of metal in the tissue, diseases related to or damaged skin integrity at the place of electrode application). At the time of becoming a part of the study, all patients were on certain medicament therapy regime prescribed by the endocrinologist and in the course of the study this therapy was not changed, i.e. no new medicaments were introduced.

The device that was used in the nerve conduction study was the Medtronic Keypoint of the last generation (2000). The duration of the procedure is about 45 min including the findings report. The method measures peroneal and sural nerves conduction velocity by using registered evoked potentials directly from the sensory nerves. The procedure does not require any preparation; it is performed by placement of surface (skin) and/or deep electrodes - most of the times both, which is decided by the physician who conducts the examination.

The Ethical Committee of the Clinical Center Kragujevac approved this research and all participants gave informed written consent before the enrollment. Each of those 30 patients was treated with the identical combination of physical agents: pulsed electromagnetic field (PEMP) and kinesitherapy (KTH). Physical therapy was conducted within three ten-days cycles (five days a week), with a two-month break between the cycles. Pulsed electromagnetic field was applied once a day in duration of 30 minutes, along both lower legs and feet through the antenna, by using the frequency of $10 \mathrm{~Hz}$ and intensity of 40 mT (Kosmag 60 apparatus, Kosmaj, Banja Luka, Bosnia and Herzegovina). Kinesitherapy was applied once a day for 30 minutes, according to the individually adjusted protocol; active and active-supported exercises up to the threshold of pain were used for strengthening the 
musculature of the lower extremities and for increasing the range of movements in all joints of the lower extremities.

At the reception of patients at the physical medicine and rehabilitation center and at the end of the last (third) ten-day series of therapies, the Analysis of the quality of life by the European EuroQol EQ-5D test, which consists of two parts, was applied. The first part is a questionnaire about five areas of the quality of life: mobility, self-care, usual activities, pain/discomfort and anxiety/depression. It takes a few minutes to fill out the questionnaire. The second part is a scale that is thermometer-like, so-called evaluation sale, where the subjects evaluate the quality of their overall health condition by using grades from 0 (the worst) to 100 (the best) $(7,8)$.

The Short-Form McGill Pain Questionnaire (SF-MPQ) consists of three parts. Within the first part, a patient evaluates the pain during the previous week on the scale 0 to 3. There are different types of pain: pulsed, twinge, sharp, like a spasm, hot, dull, etc. In the second part, the patient marks the spot on a line which best describes the pain from the previous week, where the beginning of the line marks state "without pain", while the opposite end of the line marks the state of "the worst possible pain" (score in millimeters from 0 to 100). The third part of the questionnaire represents the intensity of pain at the moment of testing from "no pain" (marked with 0), through low, unpleasant, hard, terrible to intolerable (marked with 5). The values of the questionnaire are from 0 to 150 (9). After the last part of the series of therapy all 30 patients underwent a control neurological examination, parameters of the nerve conduction study, European test of quality of life EQ-5D and the Short-Form McGill Pain Questionnaire (SF-MPQ).

Data are shown as median value \pm standard deviation for normal distribution, that is median and range of values for the data which do not have normal distribution. The comparison of intergroup differences was done by T-test for the data with normal distribution, or by U-test for the data which did not have normal distribution. The probability $\mathrm{p}<0.05$ was considered statistically significant.

\section{RESULTS}

In total, $11(36.67 \%)$ patients were males and 19 $(63.33 \%)$ were females. There were $8(26.67 \%)$ smokers, the mean age was $63.17 \pm 7.68(50-76)$ years, the history of diabetes lasted $12.22 \pm 7.58(0.25-26)$ years and the history of DSPN lasted $4.26 \pm 4.80(0.25-20)$ years. The mean BMI $\left(\mathrm{kg} / \mathrm{m}^{2}\right)$ was $27.26 \pm 4.56(20.9-37.30)$. The values of the tested nerve conduction study parameters are shown in Table 1. After completion of all three series of physical therapy the statistics indicated a significant increase of conduction velocity in the peroneal nerve - left $(p=0.027)$ and the sural nerve - both sides (right $\mathrm{p}=0.0063$, left $\mathrm{p}=0.005)$. Statistics indicated a significant reduction of latency for the peroneal nerve of both sides (right $\mathrm{p}=0.003$; left $=\mathrm{p}=0.006$ ).

The values of the EQ-5D-3L and EQ-VAS are shown in Table 2. Physical therapy did not result in any statistically notable improvement of neither mobility $(Z=0.000, p>0.05)$, self- care $(Z=0.000, p>0.05)$, nor operating of regular daily activities $(Z=0-1.414 ; p>0.05)$. On the other hand, the analysis of the results indicated a statistically notably high reduction of pain/discomfort after physical treatment procedures $(Z=-4.123$; $\mathrm{p}<0.001)$ and with notable difference $(\mathrm{r}=0.53)$. Besides, highly significant reduction of anxiety/depression after the physical procedures $(Z=-3.755 ; \mathrm{p}<0.001)$ with a medium difference $(r=0.48)$, as well as statistically significant increase in EQ-VAS after the physical procedures $(Z=-$ 4.804; $\mathrm{p}<0.001)$ with a big difference $(\mathrm{r}=0.62)$.

The values of the Short-Form McGill Pain Questionnaire (SF-MPQ) (Figure 1) prior to the application of the physical therapy $(87.43 \pm 24.05)$ and after the completion of the third series of physical therapy $(47.93 \pm 17.76)$ point to the statistically significant reduction of the subjects' pain intensity $(\mathrm{p}<0.001)$.

Table 1. Nerve conduction study parameters.

\begin{tabular}{|l|l|l|l|c|}
\hline Parameter & Lower limb & Before therapy & After therapy & \multicolumn{1}{c|}{$p$} \\
\hline \multirow{2}{*}{ Motor conduction velocity of the peroneal nerve } & Right & $41.04 \pm 3.71$ & $41.34 \pm 4.95$ & 0.682 \\
\cline { 2 - 5 } & Left & $40.17 \pm 3.76$ & $41.58 \pm 3.95$ & $0.027^{*}$ \\
\hline \multirow{2}{*}{ Distal latency of the peroneal nerve } & Right & $4.01 \pm 0.92$ & $3.33 \pm 0.89$ & $0.003^{*}$ \\
\cline { 2 - 5 } & Left & $3.90 \pm 1.31$ & $3.49 \pm 1.18$ & $0.006^{*}$ \\
\hline \multirow{2}{*}{ Action potential amplitude of the peroneal nerve } & Right & $4.12 \pm 2.27$ & $4.39 \pm 2.56$ & 0.457 \\
\cline { 2 - 5 } & Left & $3.74 \pm 2.33$ & $4.28 \pm 2.73$ & $0.018^{*}$ \\
\hline \multirow{2}{*}{ Sensory conduction velocity of the sural nerve } & Right & $31.68 \pm 20.93$ & $39.65 \pm 26.73$ & 0.063 \\
\cline { 2 - 5 } & Left & $29.18 \pm 22.60$ & $38.50 \pm 26.54$ & $0.005^{*}$ \\
\hline \multirow{2}{*}{ Distal latency of the sural nerve } & Right & $2.87 \pm 3.61$ & $1.77 \pm 1.33$ & 0.066 \\
\cline { 2 - 5 } & Left & $2.02 \pm 1.63$ & $1.90 \pm 1.43$ & 0.703 \\
\hline \multirow{2}{*}{ Action potential amplitude of the sural nerve } & Right & $2.98 \pm 2.31$ & $3.24 \pm 3.01$ & 0.654 \\
\cline { 2 - 5 } & Left & $2.54 \pm 2.47$ & $2.62 \pm 2.25$ & 0.987 \\
\hline
\end{tabular}

\footnotetext{
* statistically significant
} 
Table 2. EQ-5D-3L and EQ-VAS values.

\begin{tabular}{|c|c|c|c|c|c|c|}
\hline Hallmark of the quality of life & & Mean & SD & Min & Max & $\mathrm{P}$ \\
\hline \multirow[t]{2}{*}{ Mobility } & $\mathrm{B}$ & 1.0667 & 0.25371 & 1.00 & 2.00 & \multirow[t]{2}{*}{$>0.05$} \\
\hline & $\mathrm{A}$ & 1.0667 & 0.25371 & 1.00 & 2.00 & \\
\hline \multirow[t]{2}{*}{ Self-care } & $\mathrm{B}$ & 1.1000 & 0.30513 & 1.00 & 2.00 & \multirow[t]{2}{*}{$>0.05$} \\
\hline & $\mathrm{A}$ & 1.1000 & 0.30513 & 1.00 & 2.00 & \\
\hline \multirow[t]{2}{*}{ Regular daily activities } & $\mathrm{B}$ & 1.3000 & 0.59596 & 1.00 & 3.00 & \multirow[t]{2}{*}{$>0.05$} \\
\hline & $\mathrm{A}$ & 1.2333 & 0.50401 & 1.00 & 3.00 & \\
\hline \multirow[t]{2}{*}{ Pain/Discomfort } & $\mathrm{B}$ & 2.2667 & 0.52083 & 1.00 & 3.00 & \multirow[t]{2}{*}{$<0.001 *$} \\
\hline & $\mathrm{A}$ & 1.7000 & 0.53498 & 1.00 & 3.00 & \\
\hline \multirow[t]{2}{*}{ Anxiety/Depression } & $\mathrm{B}$ & 2.1333 & 0.73030 & 1.00 & 3.00 & \multirow[t]{2}{*}{$<0.001 *$} \\
\hline & A & 1.5000 & 0.57235 & 1.00 & 3.00 & \\
\hline \multirow[t]{2}{*}{ EQ-VAS } & $\mathrm{B}$ & 36.5667 & 7.72673 & 25.00 & 65.00 & \multirow[t]{2}{*}{$<0.001^{*}$} \\
\hline & $\mathrm{A}$ & 75.6333 & 10.10798 & 55.00 & 98.00 & \\
\hline
\end{tabular}

B-before treatment; A-after treatment; * statistically significant

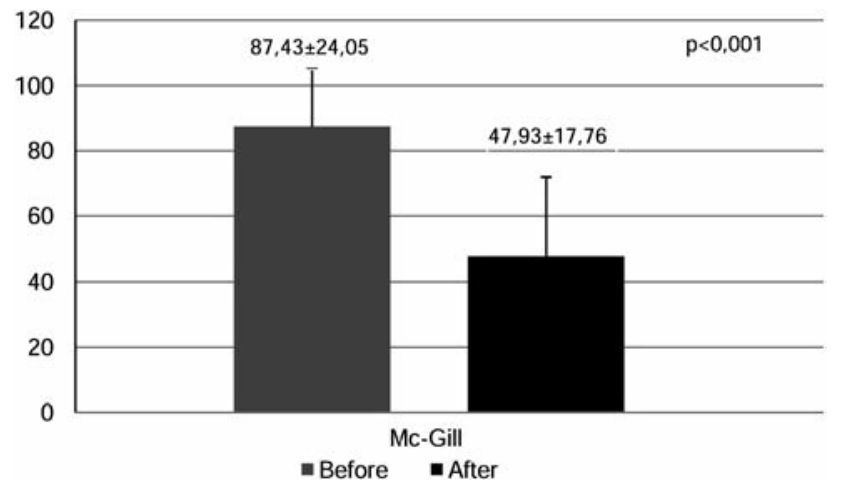

Figure 1. The Short-Form McGill Pain Questionnaire (SF-MPQ).

\section{DISCUSSION}

Research studies about the quality of life of patients suffering from DM are very common in the world, taking into account participation/prevalence of DM in the structure of morbidity and mortality, as well as the fact that the timely application of appropriate medicaments and physical therapy not only prevent numerous complications, but significantly improve the quality of life of patients, too.

Up to date researchers applied only a few studies that directly and comprehensively measured the quality of life of DSPN patients. It should be especially emphasized that DSPN does not only affect functional aspect, but psychological and emotional aspects of life of the patient as well, which significantly degrades the quality of life. DSPN is almost always accompanied with mood changes, and often with anxiety and depression. EQ-5D questionnaire provides enough information about the quality of life of patients suffering from DSPN, from the section that refers to estimation of worry/apathy, i.e. anxiety/depression (terms used in original questionnaires in English).
Apart from the sensation of pain, the patients interviewed in this survey evaluated the above noted parameters with the worst grades. Such results indicate that the psychological status is correlated to pain, the consequential problems in mobility, and to restrictions in independent functioning. The results of this study also indicate that physical therapy and rehabilitation program have positive impact on the quality of life of diabetic patients, which is manifested by the upgraded quality of life evaluated by means of EQ-5D questionnaire.

This study outlines that application of electromagnetic therapy and KTH lead to improvement of electrodiagnostic parameters. Our results correlate with the results of other clinical studies which have proved that application of electromagnetic therapy and KTH in DSPN patients, apart from the analgesic effect, cause the increase of conduction velocity through the peroneal nerve and the sural nerve, as well as shortening of distal latency.

The impact of KTH on the change of electrodiagnostic parameters (increased velocity, extended amplitude and shortened latency) is explained by vascular and metabolic changes which occur during exercises. Previous humane and experimental studies have led to the conclusion that short exercises stimulate the endothelium-dependent vasodilatation (10). Exercises also improve abnormal perfusion and viscosity of plasma, stimulating the delivery of oxygen (11). Also known is the effect of exercise in repeated episodes of hyperemia. Exercises cause changes in nerve function, due to improvement of $\mathrm{Na}(+) / \mathrm{K}(+)-$ ATPase activity. Increased concentration of $\mathrm{Na}(+) / \mathrm{K}(+)-$ ATPase in a mouse muscle cells during exercise has been detected in experiments (12). The importance of KTH is proved by the following indicators: lowered level of blood glucose, reduced insulin resistance, increased number of insulin receptors, reduced body weight and improved quality of life (13). Physical exercise causes vasodilatation of blood vessels in the muscles. Localized blood 
circulation may increase 10 to 20 times, in order to provide muscles with oxygen and other nutritive substances and to eliminate products of septic process and mediators of infection, producing the analgesic effect as well (14).

The study, which included 78 patients with distal sensorimotor polyneuropathy, investigated the effects of $\mathrm{KTH}$ on conduction velocity, latency and amplitude, applied on the nerves of the legs. The KTH program included 31 patients (the main experimental group), while 47 patients without KTH program formed the control group. After four years of therapy, the group of patients with KTH demonstrated a significant increase of conduction velocity in the peroneal nerve $(48.3 \pm 2.48$, after 4 years $48.8 \pm 2.24$ ) followed by increase of velocity in the sural nerve $(47.1 \pm 4.01$, after 4 years $47.5 \pm 3.18)$. On the other hand, the control group demonstrated a significant reduction of conduction velocity in the sural nerve (47.0 \pm 3.5 , after 4 years $44.3 \pm 7.84)$ (13). Fisher et al. proved that ischemia is an important factor in diabetic neuropathy pathogenesis. They found that after a 24week-long KTH followed by electromyography the nerve function improved in patients with DM II (15).

Analgesic effect of the electromagnetic field is explained by the hyperpolarization of the cell membrane, increased production of endorphin and normalization of the blood and lymph circulation and blood $\mathrm{pH}$. In our study, PEMP, besides its analgesic effect, was shown to improve several other functional peripheral nerve parameters. The effect the electromagnetic field (600-800 $\mathrm{Hz}$ frequency) has on the conduction velocity in the peroneal nerve and on the pain ease has been previously investigated. The research included 30 patients with diabetic polyneuropathy who were divided into three groups. The first group and the second group were treated by electromagnetic therapy with the frequency of $600 \mathrm{~Hz}$ and $800 \mathrm{~Hz}$ respectively, 30 minutes per day during 12 days, while the third group was not treated with this therapy (the control group). The first group demonstrated the increase of velocity of conduction through the peroneal nerve - right, from $36.23 \mathrm{~m} / \mathrm{s}$ to $39.44 \mathrm{~m} / \mathrm{s}$, through the peroneal nerve - left, from $36.27 \mathrm{~m} / \mathrm{s}$ to 38.92 $\mathrm{m} / \mathrm{s}$, while VAS score was reduced from 8.4 to 2.8 . The second group also demonstrated the increase of conduction velocity through the peroneal nerve - right, from $38.8 \mathrm{~m} / \mathrm{s}$ to $41.38 \mathrm{~m} / \mathrm{s}$, left, from $37.58 \mathrm{~m} / \mathrm{s}$ to 40.98 $\mathrm{m} / \mathrm{s}$, and VAS reduced from 7.9 to 2.9. Furthermore, the first two groups demonstrated an improvement of distal latency and amplitude. On the other hand, the control group showed reduction of conduction velocity through the right peroneal nerve from $38.39 \mathrm{~m} / \mathrm{s}$ to $37.86 \mathrm{~m} / \mathrm{s}$ and left from $39.35 \mathrm{~m} / \mathrm{s}$ to $37.99 \mathrm{~m} / \mathrm{s}$. This group had the least reduction of VAS: from 8 to 6.2 (16).
Bosi et al investigated the effects of high-frequency electromagnetic field on the conduction velocity through the peroneal nerve and the sural nerve. The research included 31 patients with painful distal sensorimotor polyneuropathy. The conduction velocity through the peroneal nerve in the group of patients with magnetic therapy was $35.7 \pm 1.3$ at the beginning, and after three weeks of therapy it was $40.5 \pm 1.8$. The conduction velocity through the sural nerve was $30.4 \pm 2.9$ at the beginning and after three weeks of therapy it was $33.0 \pm 2.3$. At the end of the investigation, the main experimental group of patients reported a statistically significant reduction of pain which was confirmed by VAS scale (before the treatment: $\mathrm{VAS}=37.1 \pm 5.3$, after the treatment: $\mathrm{VAS}=26.2 \pm 3.9$; $\mathrm{p}=0.0025$ ), however without a statistically significant improvement of the quality of life that was measured by the Short-Form McGill Pain Questionnaire (SF-MPQ) (before the treatment $103.7 \pm 1.5$, after the treatment $105.6 \pm 1.3 ; \mathrm{p}>0.05)(7)$. The control group did not demonstrate any improvement of conduction velocity (motor nerve conduction velocity at the beginning $37.2 \pm 1.2$, at the end $37.4 \pm 1.4$; sensory nerve conduction velocity at the beginning $31.9 \pm 2.1$, at the end $30.2 \pm 2.7$ ) (17).

In conclusion, physical therapy applied on the patients with DMPN is a continuous process due to which the patients improve their functional abilities and functional independency, and therefore it has a significant benefit for the patients' quality of life. Physical therapy also causes positive changes of electrodiagnostic parameters: increased conduction velocity through motor and sensory nerves, increased amplitude and shortened latency. The results attained in this research encourage further use of physical therapy agents in treatment of DSPN.

\section{ABBREVIATIONS}

DSPN - distal symmetric sensorimotor polyneuropathy

NCS - nerve conduction study

DM2 - type 2 diabetes mellitus

PEMP - pulsed electromagnetic field

$\mathrm{KTH}$ - kinesitherapy

SF-MPQ - the Short-Form McGill Pain Questionnaire

\section{REFERENCES}

1. Boulton AJ, Vinik AI, Arezzo JC, et al. Diabetic neuropathies: a statement by the American Diabetes Association. Diabetes Care 2005; 28: 956-62.

2. Gordois A, Scuffham P, Shearer A, Oglesby A, Tobian JA. The health care cost of diabetic peripheral neuropathy in the US. Diabetes Care 2003; 26: 179095 . 
3. Daousi C, MacFarlane IA, Woodward A, Nurmikko TJ, Bundred PE, Benbow SJ. Chronic painful peripheral neuropathy in an urban community: a controlled comparison of people with and without diabetes. Diabetes Med 2004; 21: 976-82.

4. Jung SJ, Pfeifer MA. Person with diabetes and neuropathic symptoms have poor psychosocial adjustments. Diabetes 1986; 35 Suppl: 123.

5. Petrovic D, Nikolic A, Stojimirović B. Clinical importance control of risk factors in prevention of progression of diabetic nephropathy. Med Čas 2010; 44: 19-27. (in Serbian).

6. International Diabetes Foundation. Diabetes: A global Treat. Brussels: International Diabetes Foundation, 2006: 1-15.

7. The EuroQol Group. EuroQol: EQ-5D-3L User Guide. Basic information on how to use EQ-5D-3L instrument. Version 4.0. 2011: 1-24. (http://www.euroqol.org/fileadmin/user_upload/ Documenten/PDF/Folders_Flyers/UserGuide_EQ-5D3L.pdf).

8. Solli O, Stavem K, Kristiansen IS. Health-related quality of life in diabetes: The associations of complications with EQ-5D scores. Health Qual Life Outcomes 2010; 8: 18.

9. Dworkin R, Turk D, Revicki D, et al. Development and initial validation of an expanded and revised version of the Short-form McGill Pain Questionnaire (SF-MPQ2). Pain 2009; 144: 35-42.
10. Gustafsson T, Puntschart A, Kaijser L, Jansson E. Increased expression of vascular endothelial growth factor in human skeletal muscle in response to shortterm one-legged exercise training. J App Physiol 2002; 99: 1219-26.

11. Fuchsjager-Mayrl G, PleinerJ, Wiesinger GF, et al. Exercise training improves vascular endothelial function in patients with type 1 diabetes. Diabetes Care 2002; 25: 1795-801.

12. Kjeldsen K, Richter EA, Galbo H, Lortie G, Clausen T. Training increases the concentration of $[3 \mathrm{H}]$ ouabainbinding sites in rat skeletal muscle. Biochim Biophys Acta 1986; 860: $708-12$.

13. Balducci S, Iacobellis G, Parisi L, et al. Exercise training can modify the natural history of diabetic peripheral neuropathy. J Diabetes Complications 2006; 20: 216-23.

14. Nedvidek B. The basic of physical medicine and rehabilitation. 3rd ed. Novi Sad: Medical Faculty, 1991. (in Serbian)

15. Fisher MA, Langbein WE, Colins EG, Williams K, Corzine L. Physiological improvements with moderate exercise in type II diabetic neuropathy. Electromyogr Clin Neurophysiol 2007; 47: 23-8.

16. Graak V, Chaudharz S, Bal BS, Sandhu JS. Evaluation of the efficacy of pulsed electromagnetic field in the management of patients with diabetic polyneuropathy. Int J Diab Dev Ctries 2009; 29: 56-61.

17. Bosi E, Conti M, Vermigli C, et al. Effectiveness of frequency-modulated electromagnetic neural stimulation in the treatment of painful diabetic neuropathy. Diabetologia 2005; 48: 817-23. 